\title{
From Municipalist Activism to Institutional Changes: An Analysis of the Subnational Dimension in Mercosur (1995-2019)
}

\section{Cairo Gabriel Borges Junqueira*}

\begin{abstract}
Mercosur has gone through distinct phases, leading to the articulation between a myriad of sectors, groups, and actors, among which subnational governments stand out. Local governments started this movement in 1995, with the foundation of the Mercosur Cities Network. In 2000, the Specialized Meeting of Municipalities and Intendencies (REMI) was created, replaced in the following years by the Mercosur Advisory Forum of Municipalities, States, Provinces, and Departments (FCCR), known for being the channel for subnational representation in the bloc. Drawing on bibliographic and document analysis, in addition to interviews and questionnaires, this article aims to analyze the internationalization and inclusion of subnational actors in Mercosur, mainly focusing on the changes observed over the years within these three institutions. The first section introduces the literature on paradiplomacy and deals specifically with Mercosur, seeking to verify how the regional agenda has been expanded, despite decision-making processes not being decentralized. The second and third sections analyse the origins of subnational integration through Mercocities alongside the development of REMI and FCCR. Considering the historical and institutional specificities of Mercosur, the research concludes by questioning the assumption of International Relations literature that regional blocs are potential arenas for effective internationalization of subnational governments.
\end{abstract}

Keywords: Mercosur; Mercocities; FCCR; subnational governments; cities; paradiplomacy.

\section{Introduction}

The 1990s has been seen as a period of great uncertainty in international relations, and marked by a striking feature: the emergence of new international actors. In addition to nation-states, international organizations, transnational companies, and non-governmental organizations, other entities such as political parties, bureaucracies, chambers of

* Federal University of Sergipe (UFS), São Cristóvão - SE, Brazil; cairojunqueira@gmail.com. ORCiD 00000002-3753-9769. 
commerce, universities, and public opinion, have become increasingly involved in international politics.

This movement was the result of transformations from previous decades and developed concurrently with the emergence of new theoretical and conceptual perspectives that aimed to explain the constant interrelationship between different levels of analysis of international relations. Foreign Policy Analysis has paid more attention to factors of change in systemic or international, national, or even individual terms, including the role of leaders and politicians (Lima 1994; Cason and Power 2009). Liberal theories placed greater emphasis on the interaction of social actors and decision-making interdependence, resulting in analytical perspectives that relativized state sovereignty and pointed to the importance of domestic actors and international institutions as fundamental to understanding the global political game.

Furthermore, in the 1990s the Constructivist and Governance approaches also reached levels of greater development. The former has contributed to unveil the factors of change and transformation of the international system (Stuart 2002) from a more reflective and subjective outlook, while the latter began to challenge the borders between the internal and the external, and even domestic and international policies (Aalberts 2005). In short, these approaches have focused on explaining the domestic-international relationship, placing this interconnection as fundamental for understanding the discipline.

In this process, two academic fields of International Relations - which also represent different levels of analysis and the focus of this investigation - have also been developed: regional integration and paradiplomacy. The first investigates the creation of regional blocs while the second corresponds to the decentralized international insertion of subnational governments, which may complement or challenge central and state policies. Even though the concept is used widely in academia, the term 'paradiplomacy' is controversial and has a series of synonyms, such as subnational international action (Junqueira 2017). Overall, paradiplomacy is defined as the international insertion of subnational governments such as cities. ${ }^{1}$

Regional blocs appear as one of the most fruitful topics, encompassing theoretical and conceptual approaches, for studying the internationalization of subnational actors (Oddone 2016). Most research has focused on the European Union (EU), for having successfully generated participation by subnational governments, mostly due to the creation of the EU's Committee of the Regions (CoR). The CoR is a body responsible for representing subnational interests that was established through collective principles and common values (Stuart 2002) with the development of European integration, which has even impacted the bloc's enlargement processes (Öner 2004).

In the meantime, studies on the Southern Common Market (Mercosur) increased qualitatively and quantitatively by shedding light on governance perspectives in the regional arena. If the CoR represented the inclusion of subnational aspirations and agendas within the EU, how has this process developed in Mercosur? Intending to question the argument, widely accepted in the literature, that regional organizations would be potential arenas for effective subnational internationalization, this article focuses on the role of subnational governments within the scope of the Mercosur. 
In two foundational and fundamental documents of Mercosur, the Treaty of Assunção (1991) and the Protocol of Ouro Preto (1994), there was not even mention of the inclusion of bureaucratic or even technical apparatuses for the member countries' subnational governments. However, this relation between subnational governments and Mercosur started in 1995, when the Mercosur Cities Network, known as Mercocities, was created.

Although the international insertion of subnational governments in Mercosur does not assume the form known as protodiplomacy, that is, the political division and conflict through which subnational governments seek to achieve sovereignty and independence (Prado 2018), the cities' international movement at the beginning of Mercocities was the opposite of the guidelines adopted by central governments. The latter were handled by the liberal economic guidelines characteristic of 'open regionalism' (Saraiva 2012) and, in contrast, the local governments that founded Mercocities had distinct political preferences with more progressive bias. In summary, the creation of the Network took place as a relative parallel movement to Mercosur in its early years.

This raises a paradox. If, on the one hand, such a path provided greater autonomy to cities, being politically tied much more to Montevideo - where the headquarters of the Mercocities are located - on the other hand it caused problems of legitimacy through Mercosur itself. Mercocities started this process, but generated a problem to local governments, since the Network's functioning and structures were not formally inserted in the bloc's organizational chart. Mercocities desired to create a formal link with Mercosur, because the network considered that it could enhance subnational voices in the region. In other words, since subnational actors are more connected with citizens' political participation, the result would be greater input legitimacy (Schmidt and Wood 2019: 728) via institutional articulation. ${ }^{2}$

One of the main objectives for municipal activism was to gain space for action within the region. This intention was partially materialized in 2000, when the Specialized Meeting of Municipalities and Intendencies (REMI) was established. REMI's activities vanished in a short period of time, showing itself to be inoperative and far from the central Mercosur decision-making bodies. For Mercosur intergovernmental structures, subnational demand has become a topic in integration that does not represent the political wills of those governments and thus has weakened REMI.

As a consequence, in 2004, the Mercosur Advisory Forum of Municipalities, States, Provinces, and Departments (FCCR) ${ }^{3}$ was formally established. However, it only started to function after three years, in 2007, becoming the representative body for municipal, state, provincial, and departmental governments in the bloc, succeeding REMI and being directly linked to the Common Market Group (GMC), for which recommendations would be issued for consideration. The Forum ended up materializing previous Mercocities' interests, but from the beginning, it was established as an advisory body, without decision-making powers, a fact that also explains its processes of stagnation and lethargy over the years (Junqueira and Mariano 2017). As stated by Medeiros et al. (2010), the intergovernmental structure of Mercosur is a main variable to enquire about the decrease of 
subnational actors' representativeness, due to the fact that the main bodies are conducted by central governments through the figure of their executive branches.

Thus, from 1995 to 2019, the time period covered by this analysis, subnational internationalization through Mercosur represented a complex process, marked by ups and downs. On the one hand, the creation of the FCCR attracted subnational participation in the bloc and showed the strengthening of Mercocities. The Advisory Forum became a formal organization in Mercosur and included other governmental levels such as states, provinces and departments. On the other hand, it ended up stagnating, becoming an 'empty space.' Why did this happen and what factors explain this non-linear movement with moments of cooperation, and others of quarrel, between central and subnational governments?

Using bibliographic and documentary analysis, in addition to interviews and questionnaires, this article aims to analyze the internationalization of subnational governments and the inclusion in Mercosur based on the functioning, structure, agenda, and above all the changes manifested in the three institutions - Mercocities, REMI, and FCCR - over the years. We took into account official publications of the mentioned institutions, with emphasis on the Annual Reports of the Executive Secretariat and the Permanent Technical Secretariat of Mercocities and the Minutes of Ordinary Meetings of the FCCR. Field research included interviews and questionnaire responses and was carried out in Brazil, Argentina, and Uruguay, mainly in the cities of Brasília, São Paulo, Buenos Aires, and Montevideo in 2016 and 2017. The field research helps to reveal the reasons for the creation and maintenance of subnational institutions over time, as well as subnational dynamics in the region. Excerpts from the interviews and questionnaire responses applied by the author to researchers, teachers, technical experts, and managers directly linked to the proposed theme are cited or transcribed. ${ }^{4}$

In addition to the introduction and final considerations, the article is divided into three sections. In the first, the debate focuses on the literature contextualizing paradiplomacy, highlighting the role of regional integration specifically in the advances and setbacks of Mercosur. The second and the third sections analyse the beginnings of subnational integration through Mercocities and its development through the REMI and finally the FCCR. The present study concludes that the argument pointed out by the literature in the area is valid for Mercosur in the case of very specific types of subnational governments, rather than being generalizable.

\section{Subnational actors and the specificity of Mercosur}

It was only in the 1980 s that the specialized literature began to establish a bolder conceptual framework for the phenomenon of subnational units' internationalisation conceptualised as paradiplomacy, a fact confirmed with the creation of the term 'parallel diplomacy' by Panayotis Soldatos (1990). Furthermore, subnational actors began to be inserted in different observation lenses, generating so-called 'management models' (Junqueira 2014) or even theoretical perspectives of paradiplomacy (Oddone 2016). In total, there are five 
bases for the IR theoretical understanding of subnational governments: as a) international actors; b) participants in foreign policy decision-making; c) constituent parts of cities networks; d) constituent parts of governance arrangements; e) articulators via regional integration.

When subnational governments are referred to as international actors, they are part of global politics, mobilize resources, have their own interests, and have partially decision-making autonomy. Several authors place Foreign Policy as interdependent with domestic policy, in other words, State's foreign policy reverberate what occurs within the State, whether at the domestic or subnational levels. One of the great examples is found in the debate about federations, which represented a relevant segment of the literature in the area, especially in the 1980s (Kuznetsov 2015) because federal systems entail political decisions with greater openness and decentralization.

Cities networks comprise mechanisms created by local governments for cooperation and information exchange in several areas such as education, environment, human rights, culture, technology, health, and infrastructure, having been strongly stimulated in the 1990s and 2000s (Meneghetti Neto 2005). For example, the United Cities and Local Governments (UCLG) created in 2004 is the largest in the world and one of the most recognized in the area. As it is going to be approached, the Mercocities is one of the best regionally based organizations of local governments.

Regarding governance arrangements, paradiplomacy is observed as part of an ordering system that increasingly implied a continuous shift of authority, both externally, in the supranational sense, and internally, in the subnational level (Rosenau and Czempiel 2000). Consequently, the fixed dictates of state sovereignty have weakened.

Finally, regional blocs became potential arenas for the development and expansion of subnational actors' agendas, actions, and initiatives. IR researchers began to analyse this correlation due to the appearance of CoR in 1992, established by the Maastricht Treaty. Although CoR is also a consultative body, it took shape in a moment when the principle of subsidiarity indicated greater autonomy to local governments and regions' direct participation in EU policies (Stuart 2002). Considering that statement valid for the European case, this article aims to investigate the phenomenon in South America focusing on Mercosur.

Taking into account Mercosur's institutional framework, the bloc is entirely intergovernmental, meaning that the organization decision-making process depends directly on the governmental interests of member States. Furthermore, it has a broad organizational structure that makes its operation difficult (Figure 1). 
Figure 1. Mercosur Organisation Chart

\section{ORGANIGRAMA MERCOSUR}

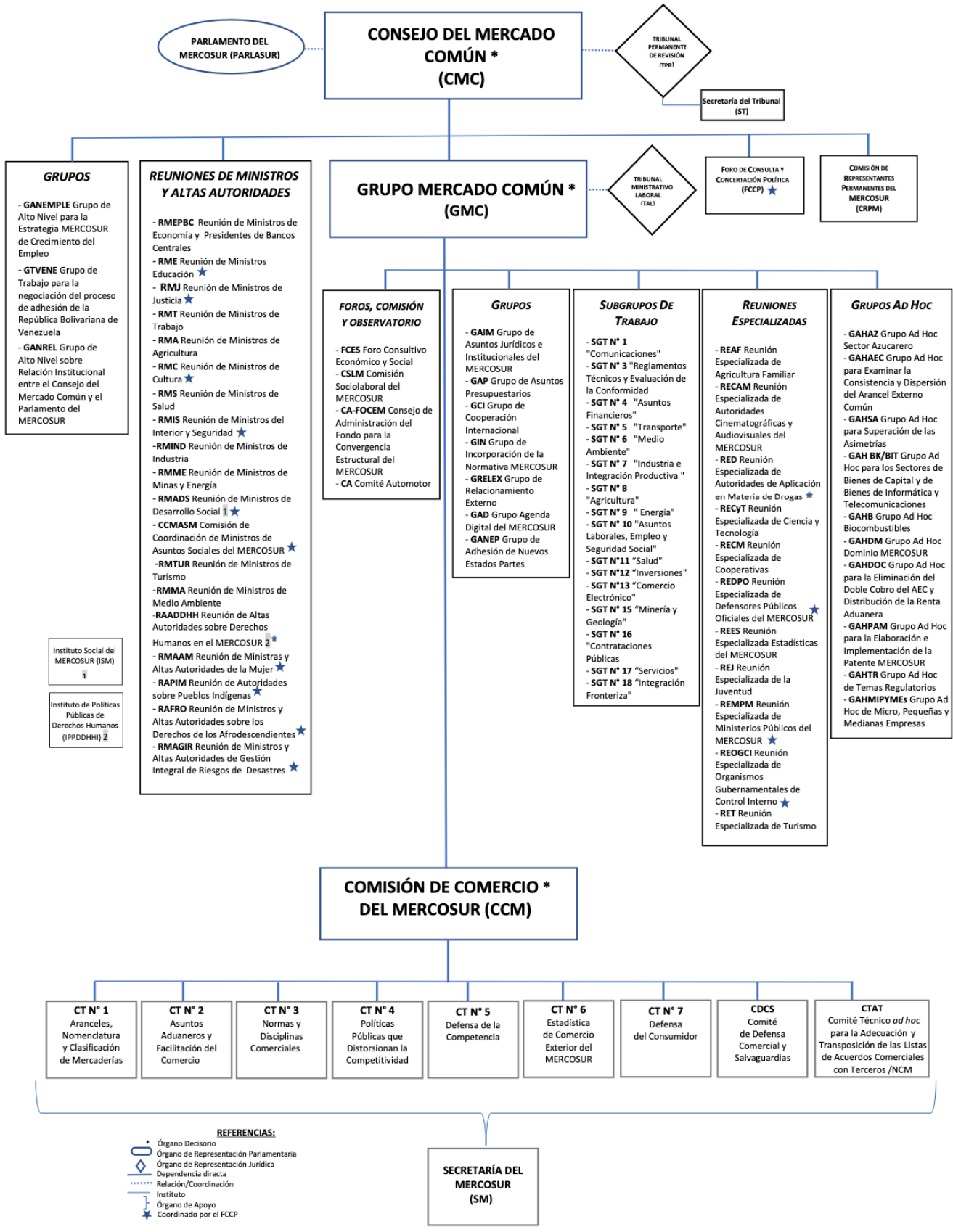

Source: Mercosur (2019b). 
The insights of Daiana Ferraro, Former Technical Adviser for Mercocities and Coordinator of the Mercosur Secretariat between 2015 and 2017 (interview, 01 December 2016, translated), and Rafael Reis, Head of Office of the High Representative-General of the Mercosur in 2016 (interview, 30 November 2016, translated) are instructive:

The organization chart is an impossible thing, absolutely ridiculous, it is not logical. [...] Mercosur does not have time to update the organization chart. [...] Each semester we end up with two more bodies.

There are problems of our own [...] on the one hand it is related to the organization chart, we have created numerous intergovernmental spaces that, on the one hand, are interesting, as we broaden the spectrum of public policies [...]. A major problem for Mercosur is the general increase in its size [...] without the necessary advice of supranational spaces. [...] We can no longer follow, in my opinion, the logic of the pro tempore presidencies to continue certain agendas and others to set aside. [...] There is a great discontinuity in the construction of public policies every semester due to the change of pro tempore presidencies. This is quite a notorious thing.

If, on the one hand, organizational extension presents itself as a problem, on the other, the establishment of new institutions in the 2000s ended up fostering new agendas and pressure for reform regarding the bloc's centralization. Thus, structures such as Parlasur, Economic-Social Consultative Forum (FCES), Permanent Review Court (TPR), Mercosur's Fund for Structural Convergence (FOCEM), Mercosur Social Institute (ISM), Social Participation Unit (UPS), the Public Policy and Human Rights Institute (IPPDH) and the FCCR represented this development.

In terms of agenda, centralization has been disrupted, but, when it comes to decision-making, it has not. From the 1990s to the 2000s, there was a change in themes dealing with integration, moving from a predominantly commercial agenda to other more political, social, infrastructural or even cultural agenda, inaugurating the so called 'post-liberal regionalism' or 'post-hegemonic regionalism' (Riggirozzi 2012).

More broadly, Latin American integration, including Mercosur, is characterized by three aspects: democratic instability, low degree of interdependence, and inadequate institutionalization (Malamud and Castro 2007). This can be explained by the fact that South American regionalism represents particular preferences of the States, resulting in a dynamic interrelationship, that is, changes in internal order end up bringing about transformations at the regional level. Considering the existence of an institutional culture articulated in sovereignty, integration ends up taking on a state-centric characteristic, hindering impulses that go beyond central interests (Serbin 2010). In this sense, Mercosur has two evident structural features: countries' lack of interest in its deepening and the maintenance of intergovernmental arrangements.

Due to these characteristics, Mercosur seems to be in a constant 'crisis. This word appears in several analyzes, such as Vigevani et al (2008) and Briceño Ruiz (2013), that 
portray the bloc's modus operandi as constant crisis. Two important events stand out that demonstrate these crisis moments: the suspensions of Paraguay in 2012 and Venezuela in 2016. As decisions in the bloc are taken by consensus, when disagreements prevail, there is a lack of institutional mechanisms to manage such situations. Only the suspension of certain members remains as an alternative. Cooperation and multilateralism suffer almost immediate consequences and, in both events mentioned, they practically rendered them inoperative.

Furthermore, these structural dimensions coexist with two others of a circumstantial nature: the dependence of integration on the alignment of political parties and political views in national governments; and change of national political leaders. The initial rapprochement between Raúl Alfonsín and José Sarney exemplifies this finding, with a similar movement, for example, between Lula da Silva and Néstor Kirchner with the Buenos Aires Consensus in 2003. The opposite also occurs, following the example of recent frictions and distances involving the Brazilian and Argentine parties in the figures of Jair Bolsonaro and Alberto Fernández. Besides, these early developments show a period of great uncertainty in South American regionalism, with Mercosur falling within this scope and showing that the current Brazilian government is politically moving away from the region (Caetano, Burian and Luján 2019), with Jair Bolsonaro being the main exponent of the current 'political shift to the right' in the Southern Cone.

Even with all the problems presented, Mercosur remains and continues to represent an important commercial initiative and sphere for dialogue in the region. Its creation and maintenance are rooted in central governments and national Executives, who do not want changes and seek to preserve their decision-making prerogatives. Its history is not linear, quite the opposite. During the 2000s, one of the relevant changes was the inclusion of other sectors and actors to the chart body, meeting the plurality of agendas around social guidelines. The major problem is not found in this transformation, but in the lack of change in decision-making models. New actors and themes were included, but the final decision is still up to the specific sectors that participated in the bloc's creation in 1991: national bureaucracies.

Accordingly, this transformation of the integrationist agenda did not proceed linearly. In the 2010s, especially since Dilma Rousseff's government in Brazil, the idea of 'dynamizing' the bloc was reestablished, reverting from the social agenda to a more commercial one (Saraiva e Silva 2019). This trend was recently exemplified by the signing of European Union-Mercosur Trade Agreement in June 2019 during Jair Bolsonaro's administration, bringing guidelines already implemented by former President Michel Temer.

In short, with ups and downs, there was dynamism in agenda but not in a decision making. Such context denotes the pathway followed by Mercosur subnational governments over the last decades, from a vast municipal mobilization to the FCCR's subsequent stagnation. This process was manifest in Mercocities, which aimed to influence the regional bloc and to boost the voices of local governments. It is worth saying that these aims were partially achieved, but at times the attempt showed more difficulties than advances. 
Thus, it appears that Mercosur's structural and cyclical characteristics directly impacted subnational actions from 1995, with the creation of the Network, until 2019 with the demotion of the FCCR ${ }^{5}$. These observations, the fact that the Advisory Forum has been emptied over the years and that Mercocities has remained a permanent institution of subnational ties even though it is outside the institutional and regional frameworks, are clear examples of how this process has unique characteristics around the specificities of South American regionalism. Paradiplomacy in Mercosur is a sui generis process that just validates recent studies about New and Comparative Regionalism, for example, attesting that regionalism itself is not a 'European trademark' and each region has its own dynamics (Acharya 2012).

\section{Municipalist activism in Mercocities}

Mercocities is the main city network in South America (Rodrigues and Mattioli 2017) and its constitutive agreement - the Declaration of Assunção - was signed by eleven cities in 1995. At the beginning and over the years, these actors observed the need to generate their own proposals with respect to regional integration because at the threshold of the bloc there was no subnational institutionalization (Oroño 2009). What initially was the goal of only a limited number of local governments ended up reaching broader quantitative proportions. As of 2019, Mercocities brought together almost 350 members from ten different countries in the region, covering a population contingent of approximately 120 million people (Mercocities 2020a).

According to Eduardo Mancuso, Coordinator of International Relations for the City Halls of Porto Alegre, Guarulhos and Canoas from 2002 to 2011 (interview, 12 May 2017, translated): 'The economic crisis of the neoliberal project in Latin America in the late 1990s and early 2000s was the scenario for the rise of democratic civil society struggles and the victories of progressive political and electoral movements in the national and subnational spheres [...]'. Leonardo Mércher, Researcher at the Center for Research in International Relations at the Federal University of Paraná (NEPRI/UFPR) (interview, 30 July 2017, translated) affirms:

In the 1990s there was a fad and excitement for cities to take advantage of international chances without knowing very well their means and consequences. In the 2000s, cities started to develop more awareness of IR [international relations], especially because they set up management teams and local academics with greater knowledge about paradiplomacy. If there was only interest in the first decade, in the 2000s, some cities started to have interests and awareness, mixing with the regional scenario.

One of the most interesting points about the Network lies in the fact that it arose as a voice of resistance from subnational governments, regarding the policies adopted by central governments. At the time, it represented, in the words of Mariano Larisgoitia, Former 
Director of International Relations and Cooperation of the Municipality of Morón, Argentina (interview, 24 November 2016, translated): 'a space for exchange, a laboratory for the center-left prefectures that was born as something natural'. The objective was quite clear: to generate an 'alternative Mercosur' more focused on social debates. To that extent, cities were the public space of greatest contact with civil society itself, as pointed out by Jorge Rodriguez, Coordinator of the Permanent Technical Secretariat of Mercocities (interview, 01 December 2016, translated):

In 1995 the Office of International Relations was created in Montevideo ... and in that same year in November, the Mercocities was founded. It has a peculiarity: it has no bureaucracy. The entire bureaucracy of the Network comes from local governments and the City of Montevideo has the responsibility to take care of some instances, including the Technical Secretariat. [...] When the Network was created, all local governments were of different political signs than national governments, it was a space to foster regional integration with political influence and visibility ... Local governments had an integrationist vision as a common destination for the region.

This trend can also be seen in the first official documents of Mercocities. A report by the Executive Secretariat, stated that the Network is, above all, an act against the perverse naturalness of the integration processes that tend to be sustained by central bureaucracies and large oligopolistic groups and forget communities'. As an alternative, a new idea of integration was proposed 'with a more human, social, balanced and equitable content in our societies' (Mercocities 1999: 1, translated). The organization emerged without detracting from commercial integration but rather striving to link commercial issues to the social agenda. At that time Mercocities perceived the need to create a space for dialogue, consolidate itself as a representative arena for local governments and stimulate internal communication between members.

Mercocities' focus has never been on providing financial resources to subnational governments and this is one of its limiting characteristics. Conversely, it has consolidated itself as a sphere of communication and technical exchange. Even so, over the years the Network has grown considerably, as described above. To consolidate a local agenda, Mercocities ended up developing its institutional structure, currently its Organisation Chart is structured as follows (Figure 2). 


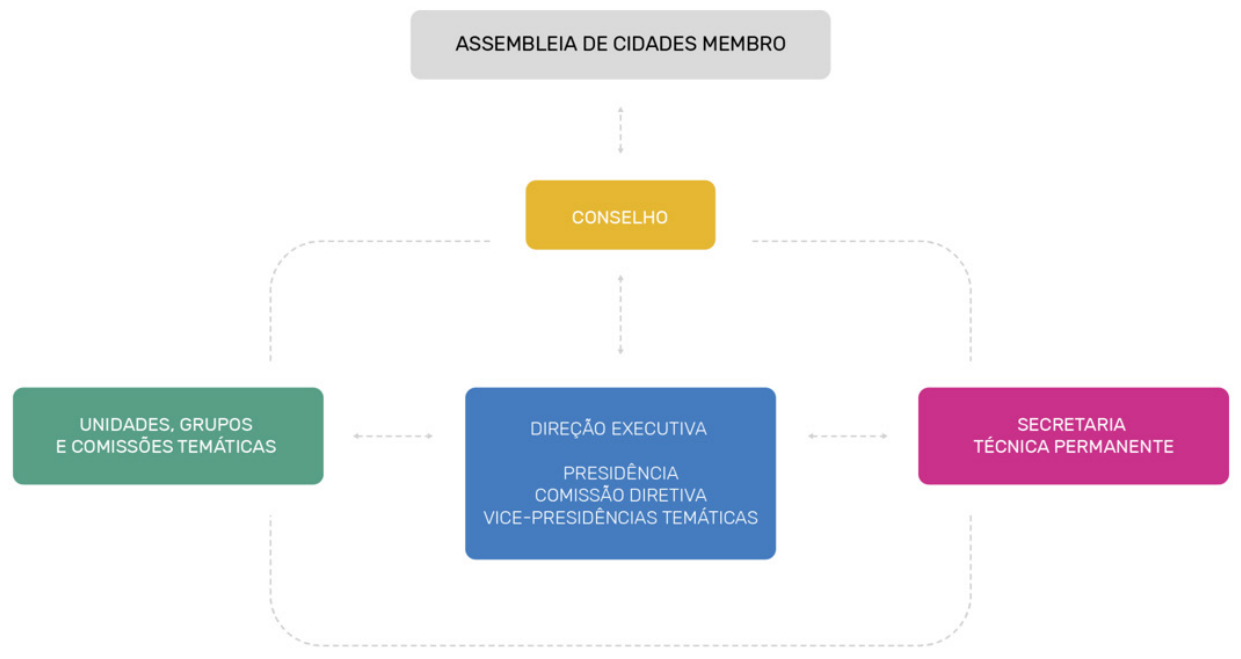

Source: Mercocities (2020b).

In addition to the administrative and directive bodies, the Permanent Technical Secretariat and Thematic Units must be highlighted. The former is responsible for advising the Executive Secretariat and managing the institutional memory of the Network. This is extremely important since keeping records of the Mercocities' work diverges from the characteristics of the FCCR, which never managed to create a technical body. Besides, and according to Fernando Santomauro, Former Coordinator of International Relations of the Municipality of Guarulhos (2009-2016) (interview, 17 February 2017, translated), the Thematic Units encompass the institutional agenda:

[...] the great richness of Mercocities are the Thematic Units and, as time went on, I saw that it is really true. As much as other things happen, it is in the TUs that the concrete things that bring some reflection in the cities happen in a more natural and easier way. A secretary goes there and sees what another secretary is doing [...] this has an impact and a meaning to the Network.

Concerning the task of the Units, in 2003 Mercocities began the process of preparing a Work Plan focused on four fundamental axes: Social and Productive Integration; Institutional Strengthening; Visibility; and External Relations (Mercocities 2004). About ten years later, this structure was updated to five central axes, distinguished between the different Thematic Units: Productive Integration (i.e., Science, Technology and Training, Tourism and Business Promotion), Sustainability (i.e., Environment and Sustainable Development and Urban Development), Social Inclusion (i.e., Culture, Education, Sport and Citizen Security), Regional Citizenship (i.e., Autonomy, Management and 
Participation, Gender and Municipality, Youth and Border Integration), and International Cooperation and Communication (Mercocities 2015: 37, 43, 45, 49 and 53, translated).

Mercocities has managed over time to establish partnerships with different organizations, including the CoR, the United Cities and Local Governments (UCLG), the World Social Forum, the Latin American Federation of Cities, Municipalities and Associations (FLACMA) and the United Nations (UN). Several partnerships with other regional institutions were also established, such as Mercosur's Fund for Structural Convergence (FOCEM), Parlasur, Mercosur Social Institute, and, more directly, the FCCR.

In terms of Mercocities' problems and precariousness, four points can be highlighted: the difference between what is in the regulations and what occurs in practice, a low percentage of annuities payments by member cities, the lack of stability in the activities presented by the Thematic Units, and the absence of formal ties with Mercosur. The anonymous report of an Argentinean subnational public manager (interview, 14 November 2016, translated) summarizes the first argument:

[...] what I experienced is that in reality and often the instances of the Mercocities Network, mainly the Technical Secretariat which is under the command of Montevideo ... has a concept of 'elite integration'. [...]. Rosario, Montevideo, Tandil, Buenos Aires ... there [is]... an integration for few cities. A large number in the quota, but few people concentrate the decisions-making. [...] The team plays there, everyone has a green and yellow shirt, everyone has the Mercocities shirt, but those are the top scorers. [...] And why does this happen and why does it continue? [...] Because most cities don't have international experience, they don't have know-how, they don't have a team, they don't know, so they go on a pilgrimage to Mecca [Montevideo].

Empirically, some cities ended up standing out and guiding internal work. Gabriela Tedeschi Cano, Undersecretary for International Relations at the Universidad Nacional del Comahue, in Neuquén, Argentina, and Marina Moraes de Andrade, Coordinator of Multilateral International Affairs and City Networks in São Paulo City Hall, Brazil (questionnaire, 21 January and 22 February 2017), mention Montevideo, Porto Alegre, Buenos Aires, São Paulo, Belo Horizonte, Guarulhos, and Rosário as examples. In general terms, large and medium-sized cities, in addition to the capitals, remained the most active in the Network. For smaller cities, participation in the regional sphere only became effective when there was political will or even thematic convergence between them and Mercocities. It is the case of small border towns, since they have significant interests when it comes to regional integration, i.e., border integration.

In the Networks Internal Regulation, annual contribution values are fixed for each member and they are proportional to the population size, with quotas ranging from US\$100 to US\$2000. For example, in 2018 Mercocities had a positive balance of approximately US\$ 110 thousand. However, in average, only around $25 \%$ of expected payments are received, placing the relative lack of resources as one of its biggest obstacles. 
The statement of Mercedes Botto, Full Professor of Political Science at the University of Buenos Aires (UBA) about Mercosur (interview, 16 November 2016, translated) also applies to Mercocities: 'There are two ingredients of success for any integration process: money and political will. There is no money, as these forums are spaces without money and resources. [...] So what exists is an space empty of content.' For the Network, political will has always been a reality, contracting the lack of resources.

In addition to the asymmetry between member cities and financial issues, the third negative point is the lack of stability. This is related to the debate on the stop and go of municipal public policies, implying that local activities, initiatives, and projects undergo alteration or even extinction due to management changes. For example, some Thematic Units such as Urban Development, Education, and Citizenship Security stopped their activities a while ago (Junqueira 2019).

The fourth negative point is the existence of a relative paradox, namely the absence of formal ties between Mercocities and Mercosur. Why 'paradox'? On the one hand, this absence of formal ties provided greater autonomy to the cities, which are linked to Montevideo - where the Network's headquarters is located - than to the bureaucratic decision-making framework of Mercosur. On the other, it created legitimacy problems with the regional bloc itself. It is questionable to what extent the inclusion of the Network in the institutional framework of Mercosur would be beneficial to local governments and their integrationist agendas, considering mainly the points dealt with in the previous section.

In its Foundation Minute, Mercocities places itself as an inter-municipal instance in order to reach active participation in the regional bloc. Such articulation has always existed, but never in an organic way, that is, in the format of institutional inclusion. For Regina Laisner, Professor at São Paulo State University (UNESP) (interview, 27 November 2017, translated), ask whether 'Mercocities [would] have more or less [...] advantages being submitted to Mercosur? I think that, in the way that Mercosur is, it would have more disadvantages [...]. But I cannot say that this is just because of the political dimension, the economic dimension is fundamental.' We must not analyse the subnational dimension only in one way, but in a plural view, including other organizations. The Network was consolidated as a fundamental actor for subnational advancement and articulation in Mercosur, being directly responsible for the creation of REMI, replaced years later by the FCCR.

\section{Ups and downs: from a failed attempt to subnational institutionalization in Mercosur}

REMI was created in 2000 through Resolution no. 90/00 of the GMC, but it only started operating the following year and had a very limited performance until 2004. In its precarious time of activity, REMI represented a demand by the Argentinean chancellery and the Mercocities, incorporating municipalities and city halls into Mercosur's legal structure (Ganganelli 2007). 
The institution had only seven meetings during approximately three years of operation (Dessotti 2009) and its documentation is very scarce. REMI became dependent on the Mercosur Political Consultation and Coordination Forum (FCCP), and was distanced from the bloc's central decision-making bodies. As a consequence, local managers did not achieve political activism, and their role became unclear because of a vast bureaucratization. In sum, the Specialized Meeting did not treat subnational governments as actors, but as mere themes present in integration.

REMI's existence was brief, and while active, its activities were fostered by capitals or large cities that had greater activism within Mercocities. The death of REMI was the result of insufficient political support and the persistence of Mercosur's intergovernmental organization. To Vicente Trevas, Deputy Chief of Federative Affairs of the Institutional Relations Secretariat of the Republic Presidency (2003-2007), Brazilian Coordinator of FCCR (2005-2007) and Brazilian Coordinator of REMI (2003-2004) (interview, 19 May 2017, translated) '[...] REMI was a mistake regarding the mayors, because REMI, in the Mercosur organization chart, was a thematic mechanism, a specialized meeting... I understood that it was an inadequate place, of low power.'

Apart from all the negative points, REMI's main achievement was the creation of an institutionalized space for local governments in Mercosur. Nonetheless, there was a distinction between subnational and central governments concerning the conception of regional integration. In the words of Ruben Geneyro, Former General Coordinator of the International Relations Directorate of the Buenos Aires City Government and Former Coordinator of the Executive Secretariat for Mercocities (interview, 06 December 2016, translated):

REMI was a milestone because Mercocities was outside the structure and it had a good link with the chancelleries [...], but [the chancelleries] did not give it an institutional space. [...] Mercosur had a national logic and in Mercocities we had a regional logic. This was an obstacle because Mercosur demanded a national perspective.

Therefore, REMI represented only some of the interests of Mercocities, but it did not create a broader subnational claim with respect to the bloc's decision-making bodies. In fact, the Specialized Meeting attempted to incorporate certain themes and raise them to the GMC, seeking greater support for the Network, including drafting a work plan comprising economic coordination, common commercial policy, treatment of asymmetries, external relations, and institutional strengthening (REMI 2001, 2003). In the last reports, REMI stated that was necessary to 'review the cities instance of participation within the institutional structure of Mercosur, considering the political value that they have in the effective development of the regional bloc' (REMI 2004: 1, translated).

Released in 2004, the FCCR, also known as the Mercosur Cities and Regions Consultative Forum, only became operational in 2007. And why did this happen? There are different explanations, although they are all part of this institutional context portrayed throughout this article. At first there was no interest from chancelleries and ministries 
regarding subnational themes (Lautaro Lorenzo, Former Under Secretary of the Agency for Sustainable Development in the municipality of Esteban Echeverria, Argentina, interview, 15 August 2017). Secondly, there was no consensus among countries regarding the FCCR functioning (María del Huerto Romero, Former Coordinator of International Cooperation in the Municipality of Rosario, Argentina, interview, 10 August 2017). In 2005, Paraguay and Uruguay did not approve the resolution to FCCR's creation and, in 2006, Brazil held presidential elections, postponing the work of the Advisory Forum for the following year.

From the first moment, the FCCR galvanized two fundamental differences in comparison to Mercocities. It became a formal and legal institution of the Mercosur organization chart - which at that time tried to underpin the increase in subnational representativeness - and started to encompass other subnational government levels, i.e., federal states, provinces, and departments. Concerning the reasons for its creation, some practioners attest that FCCR was recommended by the Mercocities while others affirm the prominent role of the Brazilian government in the figure of the Sub-section of Federative Affairs of the Republic Presidency (SAF/PR). As pointed out by Kjeld Jakobsen, Former Secretary of International Relations of the Municipality of São Paulo in 2003-2004 (interview, 27 May 2017), Mercocities, as headed by Buenos Aires, Rosario, Montevideo and Belo Horizonte, can be considered the fundamental element of FCCR. By contrast, the excerpts below show the complexity of this issue, respectively mentioned by Fernando Santomauro (interview, 17 February 2017, translated) and Paula Losada, Special Adviser at SAF/PR between 2006 and 2016 (interview, 20 July 2017, translated):

When the FCCR was created, cities felt betrayed, because it was proposed by the Pro-Tempore Presidency [PPT] of Brazil [in Mercosur] ... and SAF/PR, Vicente [Trevas] and Alberto [Kleiman] ... and what did that mean? FCCR's creation is a symbol of this process, the FCCR proposed that the representatives of the cities would be chosen by the countries... A top-down agenda. And then the staff was very indignant, Mercocities had a very autonomous role. [...] The Chancelleries of each country would choose the cities ... It was a shock. [...] The Advisory Forum represented the cities' loss of political strategy.

I was not a witness to this process, I was at SAF ... I was just there to collaborate. But then I felt... the Advisory Forum... was created... not by Mercocities initiative, I do not think so, it is... it was created by initiative and leadership, let us say, from Brazil and Argentina. But [...] it has always been a point of tension to recognize the Network as the 'FCCR Municipality Chamber' [...] Mercocities is one thing, the Forum is another. There are conflicts between them. Because the Advisory Forum is a formal instance of Mercosur. The national states are the protagonists because they are Mercosur members. 
There is no precise definition of which actors had the initiative to create the FCCR, and this also impacted the organization's development and composition. 'The FCCR constitution process [...] was marked both by the Mercocities' municipalist demand and by the efforts of the central governments of Argentina and Brazil to insert the states and provinces into the Forum' (Medeiros, Fróio and Sadeck 2017: 143, translated). The second option prevailed, giving the entity an organizational form, at its peak with 68 members from five Mercosur member states, including Venezuela (Special Secretariat for Institutional Relations of the Presidency 2010).

Some considerations regarding the FCCR composition deserve emphasis. Membership criteria were established with a political or even partisan nature, according to Mercosur members' interests. It is noteworthy to reaffirm that in Mercocities there was also a partisan political aspect in its formation. The main difference is that the Advisory Forum became effective based on central interests, that is to say, non-subnational. Additionally FCCR has never had a technical staff, a very positive mark of the Network through the role of the Permanent Technical Secretariat. In short, the FCCR ended up distancing itself from Mercocities and, according to Bruno Sadeck, Former International Advisor at SAF/PR (interview, 17 October 2016), becoming eminently political with instabilities. The anonymous report below summarizes this problematisation (interview, 14 November 2016, translated):

The Advisory Forum must be built before being used. The participation is often disappointing, cities are disappointed. [...] But what do I take to my city? You often do not take anything. [...] If you do not have an integration vision, you will think: what do I take from here to my city? [...] But the problem is there, the Forum's biggest problem is there. Everyone wants a place, then nobody wants to acquire a political problem of taking someone out. The Chancellery says: 'there are ten' [members], but of those ten, in time, some have already become opponents of the government that gave them the place, but they do not leave the FCCR... [The criterion for choosing the members of the FCCR] was political. [...] Because it is a political body ... its Chapters are composed of elected representatives.

Such developments ended up influencing the FCCR organisation chart (Figure 3). 


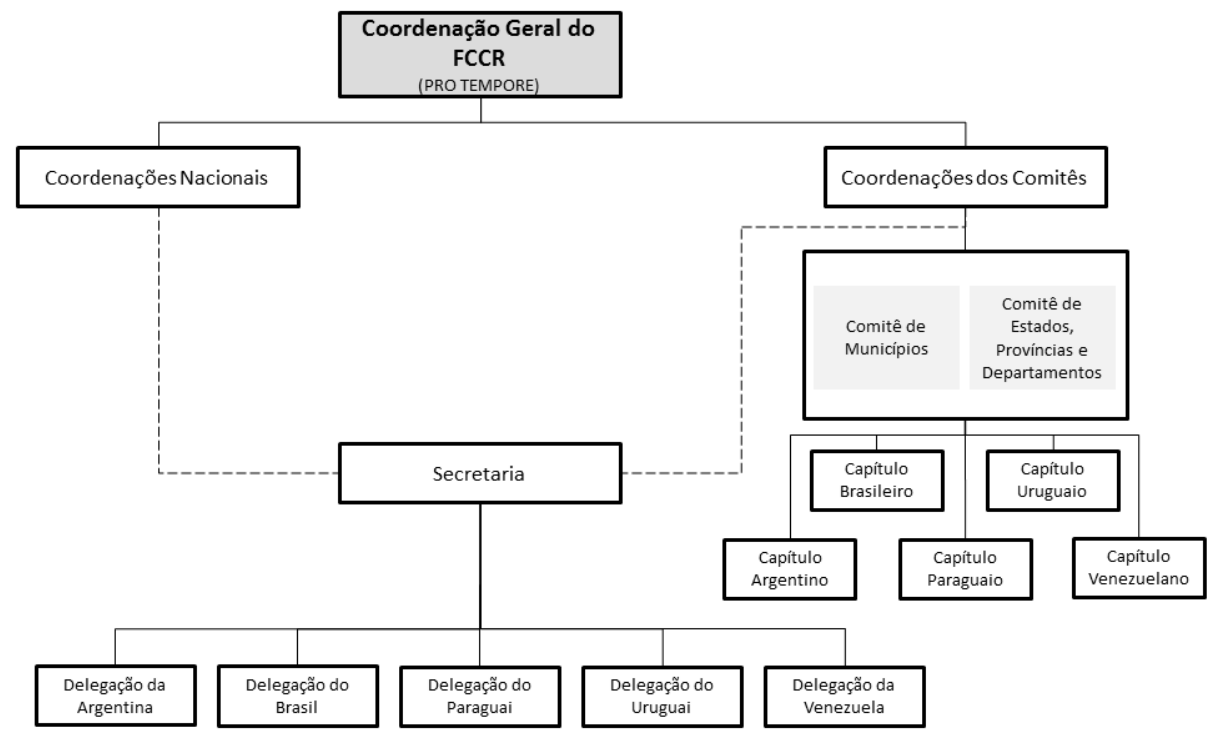

Source: Junqueira (2014: 168).

The Secretariat, in fact, never became operational due to inadequate clarification of internal organisation. Most notably, the National Coordinations were composed only by representatives appointed by each member state. Argentina and Paraguay ascribed the decisions to the Ministries of Foreign Affairs, Brazil to SAF/PR, Uruguay to the Congress of Intendants, and Venezuela to the state of Bolívar. The governmental levels were divided into two subcommittees, the one for municipalities always more active and fruitful because it was coordinated by the Mercocities' Executive Secretariat. Subnational governments' direct participation took place through National Chapters with a maximum of twenty members each.

Even so, the decision hierarchy was established within the FCCR. According to Glécio Rodrigues dos Santos, Former Coordinator of International Relations for the Municipality of Bagé, Rio Grande do Sul (questionnaire, 15 March 2017): 'Central governments do not want to let local or sub-national governments promote agendas and debates without the knowledge and the direct participation of ministries bureaucrats.' And to María Marcela Petrantonio, Coordinator of the Secretariat for International Liaison of the Municipality of Tandil, Argentina (questionnaire, 19 December 2016): '[...] the fact that central governments are the coordinators of FCCR's local agenda for Argentina and Brazil, leads to failure in recent years. [...] added to that, the institutionalisation of distinct spaces for local governments entails a weakened space without action.' As a result, Mercosur has created a sphere to subnational governments, but without real participation in the regional process. 
Regarding its agenda, the Advisory Forum formulated three Action Plans for the biennia of 2013-2014, 2015-2016, and 2017-2018. In the process FCCR formalized four central areas of action: relationship and cooperation; regional citizenship; productive integration; border integration (FCCR 2012). These last two have always been themes of interest to national governments, a fact proven by the existence of Working Subgroups 7 and 18 directly subordinate to the GMC, as shown in Figure 1.

Border integration must be highlighted, as it managed to evidently bring together subnational and national interests. Municipalities and border regions end up being affected by regional policies, making them a 'Mercosur laboratory', where several governments make decisions (Desiderá Neto and Penha 2017). As pointed out by Liliana Fróio, International Adviser at SAF/PR between 2013 and 2014 (interview, 12 October 2017), due to their geographical position, states and border municipalities have different interests, being more pragmatic, since their internationalization ends up being mandatory for the day-to-day life of governments and populations. An attempt to stimulate this debate occurred at the Advisory Forum when Brazil launched the proposal 'Mercoregions' (FCCR 2017) to create regions of cross-border cooperation in Mercosur through the establishment of bilateral treaties generating private legal associations.

Lastly, it is worth considering the FCCR's effectiveness analyzed as '[...] an ability to achieve specific outcomes or to solve problems without reference to the underlying capacity of the entity, the impact of complicating constraints, or the manner by which outcomes are achieved' (Gutner and Thompson 2010: 232). For example, for the 2013-2014 biennium, FCCR planned 52 actions, and among then, 35 were stagnant (Medeiros, Fróio and Sadeck 2017), resulting in only $33 \%$ of proposals and projects executed (Mariano and Junqueira 2018). Besides, the Advisory Forum had five main actions: issuing recommendations; issuing declarations; establishing inter and extra-institutional partnerships; carrying out projects; and developing events. Recommendations to be directly raised to the CMC through the GMC were the Forum's main function. However, between 2007 and 2012 there was no submission of a single recommendation (Ventura and Fonseca 2012), something that possibly extended until 2018, as there was no precise information in the available documents.

Finally, the FCCR experienced over the years seven main problems, both structural and cyclical: coordination of National - and not Subnational - Chapters by different levels of the Executive Power of each country, especially in the cases of the Brazil and Argentina; non-binding character in relation to the GMC; relative hierarchization of subnational members' selection, made by central governments; disparity between the activities carried out by the two Subcommittees; constant absences in meetings, implying high financial costs for subnational governments; insufficient institutional memory, a condition that was supposed to be solved with the creation of a Secretariat, but without success; and prominence of Brazilian and Argentinean subnational governments in the meetings, meaning low engagement on the part of Paraguay, Uruguay and Venezuela.

Reports show that the FCCR tried to maintain its activities until 2018. The Official Organisational Chart of the following year (Mercosur 2019b) did not include the institution 
in the blocs' structure. The FCCR thus became a non-permanent body. Moreover, when inserting the Forum's name in the official Mercosur website search sector, the last update is from January 2016 referring to the approval of the 2016-2017 Action Plan (Mercosur 2016). Furthermore, there is no inclusion in the Mercosur's website documents section, obstructing access to its plenary and ordinary minutes (Mercosur 2020).

The FCCR became aimless without a political project and thwarted subnational actors' ambitions to reach a higher level of participation in Mercosur, following the experience of REMI. The interview reports about this stagnation were assertive, and the most important ones are worth mentioning. For Valentina Falkenstein, Presidential Advisor of the Brazilian Association of Municipalities (ABM) (interview, 17 October 2016, translated): 'In practice, FCCR does not work. That is the truth... It is cool, we participate, we are called, invited [...] it is a formality. [...] It does not arouse interests, the municipalities do not feel represented ... It is cool, a moment of dialogue, but it is not going forward.' And in the words of Rodrigo Perpétuo, Former Secretary of International Relations of the Municipality of Belo Horizonte (2005-2015) (interview, 18 April 2017, translated):

National Coordinations generated the Advisory Forum, so it is a forum of mayors and governors coordinated by the national bureaucracy, except in Uruguay with the Congress of Intendants. [...] Mayors and governors did not guide that space [...] There was an attempt by the Brazilian government to try to make a strategic plan for the Forum, perhaps in tremendous myopia about the Forum's nature... from here onwards it started to languish because it did not make sense ... It was an erratic forum, without flag, without agenda, with meetings going on every six months leading nowhere.

Research reports showed that the FCCR was helpless, unstable, complex, and could not even be considered an institution. This result was caused by a combination of factors with multiple competencies at different levels: the fundamental problems of Mercosur, the centralization of power, the lack of central government's interests, and the absence of a shared identity among the subnational governments. Despite all the fundamental difficulties, the progressive discredit of the FCCR does not prove to be beneficial to subnational governments. In the current context, relaunching this agenda is a very distant goal.

\section{Final remarks}

Carrying out historical and institutional analysis of the mobilization and the consequent inclusion of subnational governments via Mercosur, it can be attested that the FCCR gained greater status, connecting subnational representatives with the decision makers, but their activities and articulations disappeared in the long run. In return, the Mercocities Network, left aside from Mercosur, gained a greater degree of autonomy. This ascertainment is the main summary of subnational activities in the Southern Cone. 
Among the 'management models' or even theoretical perspectives of paradiplomacy studies, Mercosur is part of regional integration and, with thirty years of existence, a relatively short term, has managed to bring benefits to the region. Even as the result of different dynamics and relations between levels of analysis, the bloc entailed subnational agendas and interests, highlighting strong municipalist activism. Conversely, the intergovernmental aspects of Mercosur, its centralizing and sovereign bias, dependence on political parties, and its successive crises are limiting factors for the subnational institutionalization process.

If the FCCR dissipated, the same cannot be said about Mercocities, which continues to be a fundamental institution with strong municipal activism. In the beginning, it took shape as a political contestation movement demanding new ways of thinking about regional integration in the 1990s. Despite the problems elucidated in this article, the Network expanded itself, was internally and technically organized, dynamized partnerships, and developed several projects with other organizations. In this sense and over time, it has become impossible for the Network to satisfy restricted interests of national governments, and this disconnection is the guarantor of its function as a field of cooperation and inter-municipal dialogue.

For three years, REMI showed what the work of its successor, the FCCR, would be like. Although it gained legitimacy being formally included in Mercosur's organizational chart, it never really consolidated itself, since subnational governments wanted to benefit from the institution without first consolidating it. Based on this bibliographic, documentary and empirical analysis, we enquired into the argument pointed out by the International Relations literature that regional blocks are arenas of effective potential for paradiplomacy.

For Mercosur in particular, in which cases is this statement valid? It holds up especially for municipalities that are large capitals, for local governments with political will on the part of their representatives, and for those located in border zones or borderland strips. For others, including some cities, federated states, provinces, and departments, the FCCR did not guarantee access and articulation of their interests. The Advisory Forum generated a certain cleavage between these different levels of government, not stimulating common interests and values. Its discontinuation reveals the background of this process and establishes new challenges to the current Mercosur conjuncture, which encapsulates historical characteristics of South American regionalism. The 2020s comes with new challenges to achieve a real integration between the people of the region and opens new possibilities to investigate the role performed by national and subnational institutions.

\section{Notes}

1 Academic literature on subnational actors mostly prefers the concept 'paradiplomacy' to highlight the phenomenon as used here. Furthermore, Tavares (2016: 09) summarizes the debate saying that other concepts can describe subnational internationalization 'such as 'subnational foreign affairs', 'subnational foreign policy,' 'substate diplomacy,' 'multilayered diplomacy,' 'constituent diplomacy,' 'local government external action,' 'local diplomacy,' 'local foreign policy,' 'regional diplomacy, 'plurinational diplomacy,' 'post-diplomacy,' 'microdiplomacy, or one may speak of 'foreign policy localization.' 
2 Legitimacy is an intricated concept and can be understood as 'a generalized perception or assumption that the actions of an entity are desirable, proper, or appropriate within some socially constructed system of norms, values, beliefs, and definitions' (Suchman 1995b: 574, quoted in Scott 2014: 71). It has two foundations: subjective and objective perspectives. The first is related to beliefs and customs, while the other is about norms and rules. The latter one is our focus, understanding institutional legitimacy as an entity's characteristic that is formally included and linked with a main body that makes the decisionmaking process. Finally, Schmidt and Wood (2019) distinguish three types of legitimacy in their analysis of the EU: input (political criterion), output (performance criterion), and throughput (procedural criterion) legitimacy.

3 FCCR's official acronym in Portuguese is 'Foro Consultivo de Municípios, Estados Federados, Províncias e Departamentos do Mercosul.' In this article we adopt the term 'Advisory Forum or just 'Forum' as a synonym of 'Foro Consultivo.' Other publications also use the expression 'Mercosur Committee of Municipalities, States, Provinces, and Departments.'

4 The interview and the answers to questionnaires transcribed throughout the article were used in the author's thesis, who proceeded with registration guideless at 'Plataforma Brasil' and operated under the research rules at the Ethics Committee of the university. When cited by name, respondents signed a consent term stating the use of information for academic purposes.

5 In the Institutional Chart dated December 2019 and made available on the official Mercosur website, there is no mention or inclusion of the FCCR, contrary to what was previously observed by the author in recent studies (Junqueira 2019: 87). Futhermore, the FCCR has become a non-permanent body of Mercosur, being able to hold meetings as 'Conferences' when it deems necessary (Mercosur 2019a), but, in practice, the institution is inoperative and stagnant.

\section{References}

Aalberts, T. 2005. 'Sovereignty Reloaded? A Constructivist Perspective on European Research'. Webpapers on Constitutionalism \& Governance Beyond the State, No. 02.

Acharya, A. 2012. 'Comparative Regionalism: A Field Whose Time Has Come?'. The International Spectator, 47 (1): 03-15.

Briceño Ruiz, J. 2013. 'Entre o Voluntarismo e o Realismo: O Processo de Revisão de Modelo Econômico do Mercosul'. Século XXI, 4 (2): 13-34.

Caetano, G, C Burian and C Luján. 2019. 'El Brasil de Bolsonaro, las Orientaciones Posibles de su Política Exterior y el Futuro del Regionalismo en Sudamérica'. Revista Uruguaya de Ciencia Política, 28 (1): 95-130.

Cason, J and T Power. 2009. 'Presidentialization, Pluralization, and the Rollback of Itamaraty: Explaining Change in Brazilian Foreign Policy Making in the Cardoso-Lula Era. International Political Science Review, 30 (2): 117-140.

Desiderá Neto, W and B Penha. 2017. 'As Regiões de Fronteira Como Laboratório da Integração Regional no Mercosul'. In B Penha, W Desiderá Neto and R Moraes (eds.). O Mercosul e as Regiões de Fronteira. Rio de Janeiro: IPEA, pp. 203-226.

Dessotti, F. 2009. 'Cooperação Descentralizada: Uma Inovação nas Políticas Públicas de Desenvolvimento Local'. Paper delivered at 5éme Colloque de l'IFBAE, Grenoble, 18-19 May.

FCCR [Mercosur]. 2012. Ata de Reunião Ordinária de Coordenadores Nacionais. Argentinean and Brazilian Pro Tempore Presidencies.

. 2017. Ata de Reunião Ordinária de Coordenadores Nacionais. Brazilian Pro Tempore Presidency. 
Ganganelli, M. 2007. 'La Actividad Internacional de los Municipios: La Red de Mercociudades y el Foro Consultivo de Municipios, Estados Federados, Provincias y Departamentos del Mercosur FCCR'. Estudios - Relaciones Internacionales, No. 33: 01-14.

Gutner, T and A Thompson. 2010. 'The Politics of IO Performance: a Framework' International Organization, 5 (3): 227-248.

Junqueira, C. 2014. A Inserção Internacional dos Atores Subnacionais e os Processos de Integração Regional: Uma Análise da União Europeia e do Mercosul. Master Thesis Universidade de Brasília, Brasília.

Junqueira, C. 2019. Entre Interesses e Identidades: O Que Querem e o Que São? A Atuação Internacional dos Governos Subnacionais Argentinos e Brasileiros no Mercosul (1995-2018). PhD Thesis, Programa de Pós-Graduação San Tiago Dantas (UNESP, UNICAMP, PUC-SP), São Paulo.

Junqueira, C. 2017. 'Paradiplomacia: A Transformação do Conceito nas Relações Internacionais e no Brasil'. Revista BIB, 1: 43-68.

Junqueira, C and K Mariano. 2017. 'A Internacionalização dos Entes Subnacionais Federativos: Notas Sobre os Casos do Brasil e da Argentina'. Revista Densidades, No. 22: 35-54.

Kuznetsov, A. 2015. Theory and Practise of Paradiplomacy. Subnational Governments in International Affairs. London and New York: Routledge.

Lima, M R. 1994. 'Ejes Analíticos y Conflicto de Paradigmas en La Política Exterior brasileña'. América Latina/Internacional, 1 (2): 27-46.

Malamud, A and P Castro. 2007. 'Are Regional Blocs Leading From Nation States to Global Governance? A Skeptical View From Latin America'. Iberoamericana. Nordic Journal of Latin American and Caribbean Studies, XXXVII (1): 111-130.

Mariano, K and C Junqueira. 2018. “Estagnação Subnacional” no Mercosul? Uma Análise Institucional das Mercocidades e do FCCR'. Monções, Dossiê Fronteiras, Integração Regional e Paradiplomacia, 6 (12): 337-367.

Medeiros, M et al. 2010. 'A Questão da Representação no Mercosul: Os Casos do Parlasul e do FCCR'. Revista Sociologia Política, Curitiba, 18: 31-57.

Medeiros, M, L Fróio and B Sadeck. 2017. 'Os Governos Subnacionais e o Mercosul: Um Balanço dos 10 Anos de Funcionamento do FCCR'. Revista de Estudos Internacionais, 8 (2): 139-151.

Meneghetti Neto, A. 2005. 'Redes de Cidades: Cooperação, Estratégias de Desenvolvimento, Limitações Constitucionais e Divergências - O Caso da Rede Mercocidades'. Porto Alegre: Fundação de Economia e Estatística Siegfried Emanuel Heuser.

Mercocities. 2020a. Cidades Membros. At https://mercociudades.org/pt-br/cidades-membro [Accessed on 06 July 2020].

2020b. Estrutura e Autoridades. At https://mercociudades.org/pt-br/estrutura-e-autoridades [Accessed on 15 May 2020]. 1997. Informe da Secretaria Executiva. Período 1996-1997, Porto Alegre Administration. 1999. Informe da Secretaria Executiva. Período 1998-1999, Montevideo Administration. 2004. Informe da Secretaria Executiva. Período 2003-2004, Montevideo Administration. 2015. Informe da Secretaria Executiva e da STPM. Período 2014-2015, Rosario Administration. 
Mercosur. 2016. Aprobado Plan de Acción 2016-2017 del FCCR. 20 January 2016. At https://www. mercosur.int/aprobado-plan-de-accion-2016-2017-del-foro-consultivo-de-municipios-estados-federados-provincias-y-departamentos-del-mercosur [Accessed on 22 May 2020]. 2020. Documentos Oficiais. At https://documentos.mercosur.int [Accessed on 25 May 2020].

2019a. Atualização da Estrutura Institucional do Mercosul. CMC Decision 19/19. 04 December 2019.

2019b. Organigrama MERCOSUR Completo (Oficial), 13 December 2019. At https://www. mercosur.int/documento/organigrama-mercosur-completo [Accessed on 13 May 2020].

Oddone, N. 2016. 'La Paradiplomacia Desde Cinco Perspectivas: Reflexiones Teóricas para la Construcción de una Comunidad Epistémica en América Latina'. Revista Relaciones Internacionales, Universidad Nacional, Costa Rica, No. 89.2: 47-81.

Öner, S. 2004. 'The EU and Sub-Regions. Relations Between The EU and Sub-Regions and Their Impact On The European Nation-State. Hungria: DRC Summer School: 33-48. At http://www.drcsummerschool.eu/proceedings [Accessed on 06 July 2020].

Oroño, A. 2009. 'La Cuestión Local en el Mercosur: Estado de Situación, Desafíos y Temas para una Nueva Agenda'. In Caetano, G (ed). La Reforma Institucional del Mercosur. Uruguai: Centro de Formación para la Integración Regional (CEFIR), pp. 125-150.

Prado, D. 2018 'A Atuação Internacional dos Governos Subnacionais: Construções Conceituais, Limites e Contribuições para o Caso Brasileiro'. Carta Internacional, Belo Horizonte, 13 (3): 137-168. REMI [Mercosur]. 2001. Ata da I Reunião da REMI. Assunção, Paraguay, 14 June 2001.

2003. Ata da V Reunião da REMI. Assunção, Paraguay, 20 May 2003. 2004. Ata da VII Reunião da REMI. Buenos Aires, Argentina, 4 June 2004.

Riggirozzi, P. 2012. 'Re-Territorializando Consensos: Hacia un Regionalismo Post-Hegemónico en América Latina' In Serbin, A, L Martínez, and H Ramanzini Junior. Anuario de la Integración Regional de América Latina y el Gran Caribe, CRIES, Costa Rica, pp. 129-152.

Rodrigues, G and T Mattioli. 2017. 'Paradiplomacy, Security Policies and City Networks: The Case of the Mercocities Citizen Security Thematic Unit'. Contexto Internacional, 39 (3): 569-587.

Rosenau, J and E Czempiel. 2000. Governança Sem Governo: Ordem e Transformação na Política Mundial. Brasília, DF: Ed. Universidade de Brasília.

Saraiva, M. 2012. Encontros e Desencontros. O Lugar da Argentina na Política Externa Brasileira. Belo Horizonte, MG: Fino Traço.

and A Silva. 2019. 'Ideologia e Pragmatismo na Política Externa de Jair Bolsonaro'. Relações Internacionais, 64: 117-137.

Schmidt, V and M Wood. 2019. 'Conceptualizing Throughput Legitimacy: Procedural Mechanisms of Accountability, Transparency, Inclusiveness and Openness in EU Governance'. Public Administration, 97: 727-740.

Scott, R. 2014. Institutions and Organizations: Ideas, Interests and Identities. California: SAGE Publications.

Serbin, A. 2010. 'Regionalismo y Soberanía Nacional en América Latina: Los Nuevos Desafíos'. Documentos CRIES/Nueva Sociedad, No. 15, Buenos Aires. 
Soldatos, P. 1990. 'An Explanatory Framework For The Study of Federated States as

Foreign-Policy Actors'. In Michelmann, H, P Soldatos. Federalism and international relations. The role of subnational units. United Kingdom: Oxford University Press, pp. 34-56.

Special Secretariat for Institutional Relations of the Presidency [Brazil]. 2010. Foro Consultivo de Municípios, Estados Federados, Províncias e Departamentos do Mercosul - FCCR. Presidência Pro Tempore Brasileira 2010. Foz do Iguaçu, PR, Dec.

Stuart, A M. 2002. Regionalismo e Democracia: Uma Construção Possível. PhD Thesis, Universidade de São Paulo, São Paulo.

Tavares, R. 2016. Paradiplomacy: Cities and States as Global Players. New York: Oxford University Press.

Ventura, D and M Fonseca. 2012. 'Cooperación Descentralizada e Integración Regional: Embate o Complementariedad? Los entes subnacionales en la Unión Europea y en MERCOSUR'. TIP. 1 (3), Buenos Aires, Argentina: 39-54.

Vigevani, T et al. 2008. 'O Papel da Integração Regional para o Brasil: Universalismo, Soberania e Percepção Das Elites’. RBPI, 51 (1): 05-27.

\section{Interviews and Questionnaires}

Andrade, Marina Moraes de. 2017. Questionnaire applied by the author, 22 February.

Botto, Mercedes. 2016. Personal interview conducted by the author. Buenos Aires, 16 November.

Cano, Gabriela Tedeschi. 2017. Questionnaire applied by the author, 21 January.

Falkenstein, Valentina. 2016. Personal interview conducted by the author. Brasília, 17 October.

Ferraro, Daiana. 2016. Personal interview conducted by the author. Montevideo, 01 December.

Fróio, Liliana. 2017. Personal interview conducted by the author. Skype, 12 October.

Geneyro, Ruben. 2016. Personal interview conducted by the author. Buenos Aires, 06 December.

Jakobsen, Kjeld. 2017. Personal interview conducted by the author. São Paulo, 27 May.

Laisner, Regina. 2017. Personal interview conducted by the author. Franca, São Paulo, 27 November.

Larisgoitia, Mariano. 2016. Personal interview conducted by the author. Buenos Aires, 24 November.

Lorenzo, Lautaro. 2017. Questionnaire applied by the author. 15 August.

Losada, Paula. 2017. Personal interview conducted by the author. Skype, 20 July.

Mancuso, Eduardo. 2017. Questionnaire applied by the author. 12 May.

Mércher, Leonardo. 2017. Questionnaire applied by the author. 30 July.

Perpétuo, Rodrigo. 2017. Personal interview conducted by the author. Sao Paulo. 17 April.

Petrantonio, María Marcela. 2016. Questionnaire applied by the author. 19 December.

Reis, Rafael. 2016. Personal interview conducted by the author. Montevideo, 30 November.

Rodriguez, Jorge. 2016. Personal interview conducted by the author. Montevideo, 01 December.

Romero, María del Huerto. 2017. Questionnaire applied by the author. 10 August.

Sadeck, Bruno. 2016. Personal interview conducted by the author. Brasília, 17 October.

Santomauro, Fernando. 2017. Personal interview conducted by the author. São Paulo, 17 February. 
Santos, Glécio Rodrigues dos. 2017. Questionnaire applied by the author. 15 March.

Trevas, Vicente. 2017. Personal interview conducted by the author. São Paulo, 19 May.

\section{Acknowledgements}

The article is an outcome of doctoral research and corresponds to a revised and updated version of thesis chapters defended in February 2019. Therefore, the author would like to thank the Brazilian Federal Agency for Support and Evaluation of Graduate Education (CAPES), for funding it and making possible a stay at Buenos Aires University (UBA) as a Visiting Researcher through the CAPES PPCP-Mercosur Program. He also wants to thank Professor Karina Lilia Pasquariello Mariano, who was his supervisor, Professor Lívia Peres Milani, who assisted with the article's review, Professor Jimmy Casas Klausen, for copyediting, and the anonymous reviewers for their helpful comments.

\section{About the author}

Cairo Gabriel Borges Junqueira is a Professor at the International Relations Department of the Federal University of Sergipe (DRI/UFS). He holds a PhD in International Relations at San Tiago Dantas Program (UNESP/UNICAMP/PUC-SP) funded by CAPES, MA in International Relations at University of Brasília (UnB) also funded by CAPES, and BA in International Relations at São Paulo State University (UNESP) funded by FAPESP. His areas of research include International Institutions, Regional Integration, Regionalism and Paradiplomacy. He is a member of the Regionalism Observatory (ODR), the Núcleo de Estudos de Políticas Públicas (NEPPs), the Grupo de Reflexión sobre Integración y Desarrollo en América Latina y Europa (GRIDALE) and the Fórum Universitário Mercosul (FoMerco); and Coordinator of the International and South American Politics Research Group (GP-SUL). 


\section{Do Ativismo Municipalista às Mudanças Institucionais: Uma Análise da Dimensão Subnacional no Mercosul (1995-2019)}

Resumo: O Mercosul passou por fases distintas, levando à articulação entre uma miríade de setores, grupos e atores, entre os quais se destacam os governos subnacionais. Os governos locais iniciaram este movimento em 1995 com a fundação da Rede de Cidades do Mercosul (Mercocidades). Em 2000, foi criada a Reunião Especializada de Municípios e Intendências (REMI), substituída nos anos seguintes pelo Foro Consultivo de Municípios, Estados Federados, Províncias e Departamentos do Mercosul (FCCR), conhecido por ser o canal de representação subnacional no bloco. Com base em análise bibliográfica e documental, além de entrevistas e questionários, este artigo visa analisar a internacionalização e a inclusão de atores subnacionais no Mercosul, focalizando principalmente as mudanças observadas dentro destas três instituições subnacionais ao longo dos anos. A primeira seção apresenta a literatura sobre paradiplomacia e trata especificamente do Mercosul, procurando verificar como a agenda regional foi ampliada, mas os processos de tomada de decisão não foram descentralizados. A segunda e terceira seções analisam as origens da integração subnacional através das Mercocidades, juntamente com o desenvolvimento da REMI e do FCCR. Considerando as especificidades históricas e institucionais do Mercosul, a pesquisa conclui questionando a argumentação da literatura de Relações Internacionais de que os blocos regionais são arenas potenciais para uma efetiva internacionalização dos governos subnacionais.

Palavras-chave: Mercosul; Mercocidades; FCCR; governos subnacionais; cidades; paradiplomacia.

Received on 2 June 2020, and approved for publication on 17 September 2021. 